\title{
ANALISIS DAYA SAING EKSPOR CENGKEH INDONESIA DI KAWASAN ASEAN DAN DUNIA
}

\author{
Yonette Maya Tupamahu \\ * Staf Pengajar FAPERTAUMMU-Ternate, e-mail: ymtup@yahoo.co.id
}

\begin{abstract}
ABSTRAK
Penelitian ini bertujuan menganalisis trend ekspor cengkeh Indonesia pada tahun 20152018, menganalisis keunggulan komparatif dan kompetitif ekspor cengkeh Indonesia, Malaysia dan Singapura di pasar internasional. Data penelitian dari tahun 1980-2012, yaitu nilai ekspor cengkeh Indonesia, nilai ekspor cengkeh negara ASEAN lainnya: Malaysia dan Singapura, nilai ekspor cengkeh di dunia, nilai ekspor total Indonesia, nilai ekspor total dari 2 negara ASEAN, dan nilai ekspor total di tingkat dunia. Metode analisis data yang digunakan adalah analisis trend ekspor, analisis Revealed Symmetric Comparative Advantage (RSCA) dan Indeks Spesialisasi Perdagangan (ISP). Hasil analisis menunjukkan ekspor cengkeh Indonesia meningkat pada tahun 20152018 , masing-masing sebesar 10606,86 ton, 10943,20 ton, 11279,54 ton, dan 11615,88 ton dengan rata-rata pertumbuhan sebesar 3,08 \% per tahun. Daya saing Indonesia memiliki keunggulan komparatif yang rendah ditingkat dunia dengan nilai indeks RSCA sebesar 0,22 serta memiliki keunggulan kompetitif dengan ISP sebesar 0,46. Malaysia memiliki keunggulan komparatif yang rendah pasar dunia dimana nilai indeks RSCA sebesar -0,25. Keunggulan kompetitif Malaysia juga rendah dimana ISP sebesar -0,45. Sedangkan Singapura memiliki keunggulan komparatif yang tinggi dibandingkan Indonesia dan Malaysia, dimana rata-rata indeks RSCA sebesar 0,96. Namun Singapura memiliki keunggulan kompetitif yang rendah ditunjukkan nilai ISP sebesar-0,09, menunjukkan bahwa Singapura sebagai pengimpor komoditi cengkeh.
\end{abstract}

Kata Kunci: Daya saing, Ekspor, Revealed Symmetric Comparative Advantage (RSCA), Indeks Spesialisasi Perdagangan (ISP)

\section{PENDAHULUAN}

1.1. Latar Belakang

Indonesia merupakan salah satu negara di kawasan ASEAN (Association of South East Asian Nations) yang juga dikenal sebagai negara pengekspor produk berbasis sumberdaya alam (agro based products). Integrasi ekonomi ASEAN dalam bentuk ASEAN Economic Community (AEC) atau Masyarakat Ekonomi ASEAN, diharapkan tercapai tahun 2015 diantaranya melalui pembukaan dan pembentukan pasar yang lebih besar, dorongan peningkatan efisiensi dan daya saing (Departemen Perdagangan, 2010).

Tingkat daya saing suatu negara di kancah perdagangan internasional ditentukan oleh dua faktor, yaitu faktor keunggulan komparatif (comparative advantage) dan faktor keunggulan kompetitif (competitive advantage). Faktor keunggulan komparatif dapat dianggap sebagai faktor yang bersifat alamiah dan faktor keunggulan kompetitif dianggap sebagai faktor yang bersifat acquired atau dapat dikembangkan/diciptakan (Tambunan, 2003a). Kondisi pasar yang sudah bebas maka Indonesia harus dapat memproduksi dan mendistribuskan barang ekspor berkualitas secara efisien, sehingga mampu berdaya saing dengan produkproduk dari negara lain di kawasan ASEAN maupun dunia. 
Salah satu komoditi ekspor yang diperdagangkan Indonesia dan negara-negara ASEAN lainnya di pasar dunia adalah cengkeh. Cengkeh (Syzygium aromaticum, syn. Eugenia aromaticum) adalah tangkai bunga kering beraroma dari keluarga pohon Myrtaceae. Cengkeh atau dalam bahasa Inggris disebut cloves adalah tanaman asli Indonesia yang banyak digunakan sebagai bumbu masakan pedas di negara-negara Eropa, dan sebagai bahan utama rokok kretek (Wikipedia, 2015).

Kegunaan produk cengkeh lainnya dalam industri adalah minyak cengkeh. Bahan baku minyak cengkeh dapat berasal dari bunga cengkeh, gagang/tangkai dan daun. Pada saat harga bunga cengkeh tinggi, bunga cengkeh yang digunakan sebaiknya bunga cengkeh dengan mutu rendah atau hasil sortiran (Departemen Pertanian, 2007).

Indonesia dan Malaysia merupakan negara produsen cengkeh di kawasan ASEAN namun kontribusi ekspornya masih kecil. Singapura merupakan negara pengekspor terbesar di ASEAN dengan kontribusi 65,99\% terhadap ASEAN meskipun negara ini bukan negara produsen cengkeh, sedangkan Indonesia dan Malaysia berkontribusi $31,49 \%$ dan $2,49 \%$. Namun secara umum perkembangan volume ekspor cengkeh ASEAN pada periode tahun 19802011 menunjukkan peningkatan sebesar 20,15\% per tahun (Kementerian Pertanian, 2014).

Khusus di pasar dunia, negara-negara eksportir cengkeh terbesar juga Singapura, serta India, Indonesia, United Arab Emirates, Vietnam, Saudi Arabia, USA dan Pakistan. Kontribusi kumulatif kedelapan negara tersebut sebesar $71,84 \%$ terhadap total volume ekspor cengkeh di dunia. Singapura berada di peringkat pertama dengan rata-rata volume ekspor mencapai 11,59 ribu ton per tahun atau memberikan kontribusi sebesar $23,14 \%$ terhadap volume ekspor cengkeh dunia. Volume ekspor cengkeh dunia pada periode tahun 1980-2011 perkembangannya cenderung meningkat dengan rata-rata pertumbuhan sebesar $10,89 \%$ per tahun.

Ekspor cengkeh Indonesia dan daya saingnya masih dapat ditingkatkan, disebabkan
Indonesia memiliki keunggulan komparatif dan kompetitif dibandingkan negara lainnya di dunia serta di kawasan ASEAN. Data FAO dalam Kementerian Pertanian (2014) menunjukkan bahwa Indonesia merupakan negara dengan luas tanam menghasilkan cengkeh terbesar di dunia dengan kontribusi $79,80 \%$ dan merupakan produsen cengkeh terbesar dunia dengan kontribusi sebesar $70,99 \%$, serta rata-rata produksi 79,25 ribu ton per tahun. Peluang lainnya yaitu adanya revitalisasi pertanian agribisnis cengkeh di Indonesia akan meningkatkan produktifitas, produksi, dan ekspor. Hal ini disebabkan tanaman cengkeh di Indonesia lebih dari $\mathbf{9 0} \%$ adalah milik rakyat dan kurang dipelihara dengan baik, sehingga produktifitas tanamannya pun fluktuatif, sehingga berdampak terhadap daya saing ekspor.

Penelitian tentang daya saing ekspor Indonesia sudah banyak dilakukan oleh peneliti sebelumnya pada berbagai komoditi, seperti Hanani, dkk. (2009) mengkaji buah-buahan, Asriani (2011) mengkaji ubikayu, Rashid, dkk. (2012) mengkaji Crude Palm Oil (CPO), Ragimun (2013) mengkaji kakao, dan Ragimun (2014) mengkaji karet dan produk karet. Kajian mengenai daya saing ekspor cengkeh Indonesia ini belum dilakukan oleh peneliti lain dan analisis keunggulan komparatif yang digunakan berbeda dengan peneliti sebelumnya. Penelitian terdahulu menggunakan indeks RCA sedangkan penelitian ini menggunakan indeks RSCA. Sedangkan analisis keunggulan kompetitif menggunakan Indeks Spesialisasi Perdagangan.

Berdasarkan uraian sebelumnya maka penting dilakukan kajian tentang trend ekspor cengkeh Indonesia di waktu mendatang dan keunggulan komparatif dan kompetitif ekspor cengkeh Indonesia dengan negara ASEAN lainnya yaitu Malaysia dan Singapura.

\subsection{Tujuan Penelitian}

Penelitian ini bertujuan untuk menganalisis trend volume ekspor cengkeh Indonesia pada tahun 2015-2018 serta keunggulan komparatif dan kompetitif ekspor cengkeh Indonesia, Malaysia dan Singapura di pasar internasional 


\section{METODE PENELITIAN}

2.1. Jenis dan Sumber Data

Jenis data yang dibutuhkan dalam penelitian ini adalah data sekunder yang bersumber dari Kementerian Pertanian, Kementerian Perdagangan, dan FAO. Data yang digunakan dari tahun 1980-2011, yaitu:

1. Nilai ekspor cengkeh Indonesia.

2. Nilai ekspor cengkeh negara ASEAN lainnya:

Malaysia dan Singapura.

3. Nilai ekspor cengkeh di dunia.

4. Nilai ekspor total Indonesia.

5. Nilai ekspor total dari 2 negara ASEAN lainnya: Malaysia dan Singapura

6. Nilai ekspor total di tingkat dunia.

7. Nilai impor cengkeh Indonesia

8. Nilai impor cengkeh negara ASEAN lainnya:

Malaysia dan Singapura.

\subsection{Jenis Penelitian}

Penelitian ini tergolong penelitian deskriptif, tujuannya adalah untuk menggambarkan/ memecahkan masalah secara sistematis, faktual, dan akurat mengenai faktafakta dan sifat-sifat populasi atau daerah tertentu (Rianse dan Abdi, 2009).

\subsection{Metode Analisis Data}

\subsubsection{Analisis Trend Linier}

Analisis trend linier dianggap bahwa variabel volume ekspor dan waktu merupakan satu garis lurus. Fungsi garis lurus tersebut dinyatakan dalam persamaan (Prawirosentono, 2009) :

$$
\mathrm{Y}=\mathbf{a}+\mathbf{b} \mathbf{X}
$$

Keterangan :

$$
\begin{aligned}
\mathrm{Y}= & \text { Data volume ekspor cengkeh (ton) yang } \\
& \text { merupakan data runtut waktu } \\
\mathrm{X}= & \text { Waktu ekspor } \\
\mathrm{a}= & \text { Nilai trend pada waktu } \mathrm{X}=0 \\
\mathrm{~b}= & \text { Koefisien arah garis-trend }
\end{aligned}
$$

Rumusan yang dikembangkan dari fungsi linier tersebut diperoleh nilai $a$ dan $b$ dengan rumus:

$$
a=\frac{\sum Y_{i}}{n}
$$

$$
b=\frac{\sum X_{i} Y_{i}}{\sum X_{i}^{2}}
$$

Berdasarkan persamaan ini akan dihitung peramalan ekspor cengkeh Indonesia tahun 2015 hingga 2018 dengan menggunakan data tahun 1980-2012. Penelitian terdahulu yang menggunakan analisis ini adalah Rashid, dkk. (2012) yang mengkaji daya saing Crude Palm Oil (CPO) Indonesia di pasar internasional.

\subsubsection{Analisis Keunggulan Komparatif}

Balassa (1965) dalam Kementerian Perdagangan (2013) menemukan suatu pengukuran terhadap keunggulan komparatif suatu negara secara empiris dengan melakukan penghitungan matematis terhadap data-data nilai ekspor suatu negara dibandingkan dengan nilai ekspor dunia. Penghitungan Balassa ini disebut Revealed Comparative Advantage (RCA) yang kemudian dikenal dengan Balassa RCA Index.

Analisis daya saing ekspor cengkeh Indonesia akan ditinjau dari keunggulan komparatifnya dengan indikator RCA (Revealed Comparative Advantage). Penelitian ini juga membandingkan dan meneliti hubungan daya saing ekspor cengkeh Indonesia dengan negaranegara ASEAN khususnya Malaysia dan Singapura.

Revealed Comparative Advantage (RCA) dirumuskan sebagai berikut (Tambunan, 2004) :

$$
R C A=\frac{x_{i j} / X_{j}}{X_{i w} / X_{w}}
$$

Keterangan :

$X_{i j}=$ Nilai ekspor komoditi i di negara $j$

$X_{j} \quad=$ Nilai ekspor total negara $\mathbf{j}$

$X_{i w}=$ Nilai ekspor komoditi i di dunia

$X_{w}=$ Nilai ekspor total dunia

Bila nilai indeks RCA (Revealed Comparative Advantage) dari suatu negara untuk satu komoditi lebih besar dari nol (RCA > 1) berarti negara bersangkutan mempunyai keunggulan komparatif di atas rata-rata dunia dalam komoditi tersebut. Sebaliknya jika nilai 
indeks RCA (Revealed Comparative Advantage) dari suatu negara untuk satu komoditi lebih kecil atau sana dengan nol (RCA < 1) berarti keunggulan komparatif untuk komoditi tersebut rendah atau dibawah rata-rata dunia.

Beberapa penelitian terdahulu umumnya menggunakan indeks RCA untuk menganalisis keunggulan komparatif adalah Hanani, dkk. (2009), Asriani (2011), Rashid, dkk. (2012), Ragimun (2013), serta Ragimun (2014).

Analisis RCA memiliki keterbatasan yaitu bahwa nilai RCA dimulai dari 0 sampai tidak terhingga. Sebab itu dikembangkan Revealed Symmetric Comparative Advantage (RSCA), dengan rumus sebagai berikut (Kementerian Perdagangan, 2013) :

$$
R S C A=\frac{(R C A-1)}{(R C A+1)}
$$

Konsep RSCA membuat perubahan dalam penilaian daya saing, dimana nilai RSCA dibatasi antara -1 sampai dengan 1. Sebuah produk disebut memiliki daya saing jika memiliki nilai di atas nol, dan dikatakan tidak memiliki daya saing jika nilai dibawah nol.

\subsubsection{Analisis Keunggulan Kompetitif}

Menurut Tambunan (2003), keunggulan kompetitif suatu produk dapat diukur menggunakan analisis Indeks Spesialisasi Perdagangan (ISP) atau Trade Specialization Index. Indeks ini merupakan perbandingan antara selisih nilai ekspor dan nilai impor suatu negara dibandingkan dengan jumlah nilai ekspor dan nilai impor negara tersebut, atau dengan kata lain ISP merupakan perbandingan antara selisih nilai bersih perdagangan dengan nilai total perdagangan dari suatu negara.

Indeks Spesialisasi Perdagangan (ISP) juga digunakan untuk menganalisis posisi atau tahapan perkembangan suatu komoditi. ISP ini dapat menggambarkan apakah untuk suatu komoditi, posisi suatu negara cenderung menjadi negara eksportir atau importir komoditi pertanian tersebut. Secara umum ISP dapat dirumuskan sebagai berikut (Kementerian Perdagangan, 2013):

$$
I S P=\frac{X_{i j}-M_{i j}}{X_{i j}+M_{i j}}
$$

Keterangan :

$X_{i j}=$ Nilai ekspor komoditi i di negara $j$

$M_{i j}=$ Nilai impor komoditi i di negara $j$

Penelitian terdahulu yang menggunakan Indeks Spesialisasi Perdagangan (ISP) adalah Asriani (2011), Rashid, dkk. (2012), dan Ragimun (2013) dan Ragimun (2014).

Secara implisit, indeks ini mempertimbangkan sisi permintaan dan sisi penawaran, dimana ekspor identik dengan suplai domestik dan impor adalah permintaan domestik, atau sesua dengan teori perdagangan internasional, yaitu teori net of surplus, dimana ekspor dari suatu barang terjadi apabila ada kelebihan atas barang tersebut di pasar domestik. Nilai indeks ini mempunyai kisaran antara -1 sampai dengan +1 . Jika nilainya positif diatas 0 sampai 1, maka komoditi bersangkutan dikatakan mempunyai daya saing yang kuat atau negara yang bersangkutan cenderung sebagai pengekspor dari komoditi tersebut (suplai domestik lebih besar daripada permintaan domestik). Sebaliknya, daya saingnya rendah atau cenderung sebagai pengimpor (suplai domestik lebih kecil dari permintaan domestik), jika nilainya negatif dibawah 0 hingga -1 . Kalau indeksnya naik berarti daya saingnya meningkat, dan begitu juga sebaliknya (Departemen Perdagangan, 2008).

Indeks ISP tersebut juga dapat digunakan untuk mengidentifikasi tingkat pertumbuhan suatu komoditi dalam perdagangan yang terbagi ke dalam 5 tahap sebagai berikut :

1. Tahap Pengenalan, Ketika suatu industri (forerunner) disuatu negara (sebut A) mengekspor produk-produk baru dan industri pendatang belakangan (latercomer) di negara B impor produk-produk tersebut. Dalam tahap ini, nilai indeks ISP dari industri latercomer ini adalah -1,00 sampai 0,50 . Dengan kata lain, berarti komoditi tersebut memiliki daya saing rendah atau negara bersangkutan sebagai pengimpor suatu komoditi. 
2. Tahap Subtitusi Impor, Nilai indeks ISP naik antara $-0,51$ sampai 0,00 . Pada tahap ini, industri di negara $B$ menunjukkan daya saing yang sangat rendah, dikarenakan tingkat produksinya tidak cukup tinggi untuk mencapai skala ekonominya. Industri tersebut mengekspor produk-produk dengan kualitas yang kurang bagus dan produksi dalam negeri masih lebih kecil daripada permintaan dalam negeri. Dengan kata lain, untuk komoditi tersebut, pada tahap ini negara B lebih banyak mengimpor daripada mengekspor.

3. Tahap Pertumbuhan, Nilai indeks ISP naik antara 0,01 sampai 0,80 , dan industri di negara B melakukan produksi dalam skala besar dan mulai meningkatkan ekspornya. Di pasar domestik, penawaran untuk komoditi tersebut lebih besar daripada permintaan. Dengan kata lain, berarti komoditi tersebut dalam tahap perluasan ekspor dalam perdagangan dunia atau memiliki daya saing yang kuat

4. Tahap Kematangan, Nilai indeks berada pada kisaran 0,81 sampai 1,00. Pada tahap ini produk yang bersangkutan sudah pada tahap standardisasi menyangkut teknologi yang dikandungnya. Pada tahap ini negara B merupakan negara net exporter. Berarti komoditi tersebut dalam tahap pematangan dalam perdagangan dunia atau memiliki daya saing yang sangat kuat.

5. Tahap Kembali Mengimpor, Nilai indeks ISP kembali menurun antara 1,00 sampai 0,00. Pada tahap ini industri di negara $B$ kalah bersaing di pasar domestiknya dengan industri dari negara $A$, dan produksi dalam negeri lebih sedikit dari permintaan dalam negeri.

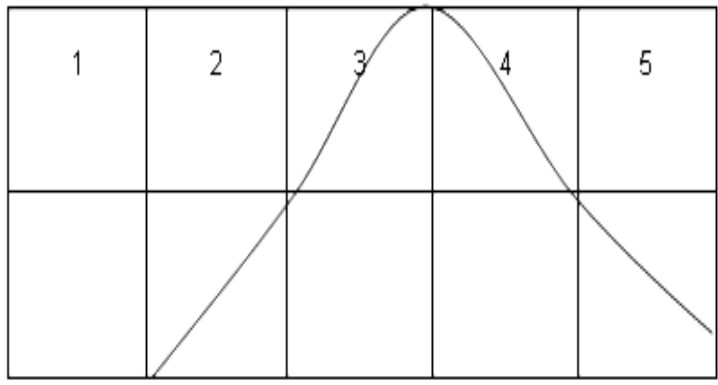

Gambar 1. Kurva ISP Sesuai Teori Siklus Produk (Sumber : Departemen Perdagangan, 2008)

\section{HASIL DAN PEMBAHASAN}

Data Kementerian Pertanian (2014) menunjukkan bahwa volume ekspor cengkeh Indonesia selama periode 1980-2013 cukup berfluktuasi, dimana volume ekspor yang tertinggi terjadi di tahun 1998 sebesar 20.157 ton. Selama periode tahun 1998-2013, volume ekspor cengkeh meningkat sebesar $359,61 \%$, sedangkan pada periode sebelumnya yaitu tahun 1980-1997 hanya sebesar $42,42 \%$.

Peramalan volume ekspor cengkeh Indonesia menggunakan data volume ekspor tahun 1980-2011. Hasil analisis trend volume ekspor cengkeh Indonesia di pasar dunia di masa yang akan datang (tahun 2015-2018) cenderung meningkat. Persamaan trend untuk ekspor cengkeh Indonesia di pasar dunia adalah sebagai berikut :

$$
Y=4216,39394+336,34024 X
$$

Adapun hasil analisis peramalan ekspor cengkeh Indonesia dapat dilihat pada Tabel 1 pada tingkat kepercayaan $95 \%$ dan Standard Error (SE) peramalan sebesar 832,02.

Tabel 1. Hasil Analisis Peramalan Ekspor Cengkeh Indonesia Tahun 2015-2018

\begin{tabular}{ccc}
\hline Tahun & Y & Pertumbuhan (\%) \\
\hline 2015 & 10606,86 & \\
2016 & 10943,20 & 3,07 \\
2017 & 11279,54 & 2,98 \\
2018 & 11615,88 & 2,90 \\
\hline \multicolumn{2}{l}{ Rata-Rata Pertumbuhan } & 3,08 \\
\hline
\end{tabular}

Sumber : Data sekunder diolah, 2015

Hasil analisis Tabel 1 menunjukan bahwa trend volume ekspor cengkeh Indonesia terus meningkat pada tahun 2015-2018. Volume ekspor cengkeh Indonesia pada tahun 2015 ini diramalkan sebesar 10606,86 ton, tahun 2016 diramalkan sebesar 10943,20 ton, tahun 2017 sebesar 11279,54 ton, dan tahun 2018 sebesar 11615,88 ton. Volume ekspor tersebut meskipun meningkat namun pertumbuhannya cenderung menurun. Namun demikian produksi cengkeh diperkirakan masih akan mengalami peningkatan dengan rata-rata pertumbuhan sebesar 3,08\% per tahun (lihat Gambar 2). Kondisi ini dimungkinkan karena cengkeh yang dihasilkan Indonesia hampir $80-90 \%$ 
diperuntukkan bagi industri rokok di dalam negeri.

\subsection{Analisis Keunggulan Komparatif}

Salah satu indikator yang dapat menunjukkan perubahan keunggulan komparatif adalah RSCA index. Indeks ini menunjukkan perbandingan antara pangsa ekspor komoditi atau sekelompok komoditi suatu negara terhadap pangsa ekspor komoditi tersebut dari seluruh dunia. Dengan kata lain indeks RCA menunjukkan keunggulan komparatif atau daya saing ekspor dari suatu negara dalam suatu komoditi terhadap dunia. Hasil analisis RSCA komoditi cengkeh Indonesia dan kedua negara ASEAN lainnya dilihat pada Tabel 2.

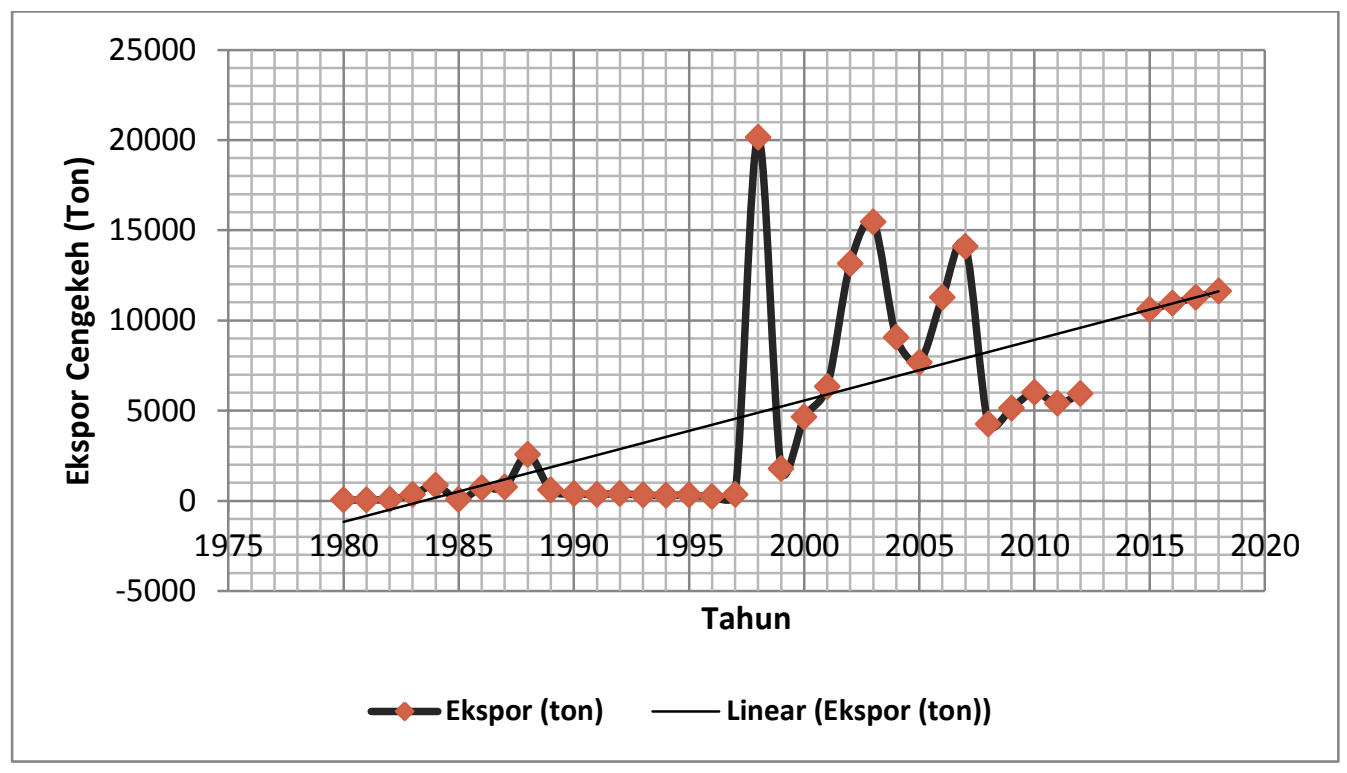

Gambar 2. Trend Ekspor Cengkeh Indonesia Tahun 2015-2018

Tabel 2. Nilai RCA, RSCA Indonesia, Malaysia dan Singapura Tahun 1980-2011

\begin{tabular}{ccccccc}
\hline \multirow{2}{*}{ Periode } & \multicolumn{2}{c}{ Indonesia } & \multicolumn{2}{c}{ Malaysia } & \multicolumn{2}{c}{ Singapura } \\
\cline { 2 - 6 } & RCA & RSCA & RCA & RSCA & RCA & RSCA \\
\hline $1980-1986$ & 0,82 & $-0,51$ & 1,58 & 0,09 & 19,85 & 1,03 \\
$1987-1993$ & 2,30 & $-0,09$ & 1,53 & 0,13 & 21,72 & 1,04 \\
$1994-2000$ & 5,29 & 0,05 & 1,38 & $-0,15$ & 15,31 & 1,00 \\
$2001-2007$ & 21,17 & 1,02 & 0,25 & $-0,76$ & 13,94 & 0,98 \\
$2008-2011$ & 4,99 & 0,64 & 0,28 & $-0,57$ & 8,47 & 0,77 \\
Rata-rata & 6,91 & 0,22 & 1,00 & $-0,25$ & 15,86 & 0,96 \\
\hline
\end{tabular}

Sumber : Data sekunder diolah, 2015

Tabel 2 menunjukkan bahwa komoditi cengkeh Indonesia selama periode waktu 19801986, 1987-1993, 1994-2000 dan 2008-2011 mempunyai nilai RSCA kurang dari 1. Berarti pada periode tersebut keunggulan komparatif cengkeh Indonesia rendah dari rata-rata dunia dan tidak memiliki daya saing. Selama periode tesebut, luas lahan dan produksi cengkeh Indonesia cenderung menurun, faktor utama penyebabnya adalah rendahnya harga cengkeh di tingkat produsen. Harga cengkeh ditingkat produsen pada tahun 1983 sebesar Rp. $7.800 / \mathrm{kg}$, turun menjadi Rp. $3.827 / \mathrm{kg}$ pada tahun 1997. Sedangkan harga pembelian dari tingkat petani berkisar Rp. 2.000,00/kg - Rp.3.500,00/kg. Harga cengkeh yang terus menurun menyebabkan petani tidak melakukan pemeliharaan atau menelantarkan tanamannya, bahkan ada petani 
yang menebang tanamannya. Pada tahun 20082009 pun terjadi penurunan produksi yang cukup besar, sehingga berdampak terhadap volume ekspor cengkeh.

Pada periode 2001-2007, nilai RSCA sebesar 1,02 berarti komoditi cengkeh Indonesia memiliki daya saing. Pada tahun 1999, harga cengkeh mulai melonjak menjadi Rp 13.966/kg dan tahun 2000 naik lagi menjadi $R p 26.824 / \mathrm{kg}$. Pada tahun 2001, harga cengkeh mencapai Rp $51.223 / \mathrm{kg}$, kondisi ini mendorong petani untuk melakukan pemeliharaan tanaman seperti peremajaan tanaman yang rusak/mati. Meskipun pada tahun 2002 dan 2003 harga sempat menurun, tetapi setelah tahun 2004 harga cengkeh terus meningkat. Secara keseluruhan, rata-rata nilai RSCA Indonesia sebesar 0,22 menunjukkan komoditi cengkeh Indonesia tidak mempunyai daya saing di tingkat dunia.

Komoditi cengkeh Malaysia selama periode waktu 1980-2011 mempunyai nilai RSCA kurang dari 1. RSCA yang bernilai negatif, maka dapat dikatakan bahwa produksi cengkeh Malaysia hanya digunakan untuk keperluan dalam negeri dan tidak berperan di perdagangan dunia sehingga tidak mempunyai daya saing di pasar global. Menurut data Kementerian Pertanian (2014), kontribusi luas areal tanaman menghasilkan Malaysia hanya sebesar 0,28\% dan kontribusi produksinya sebesar $0,34 \%$ di wilayah ASEAN.

Sedangkan Singapura, selama periode 1980-2000 memiliki nilai RSCA lebih dari 1, artinya komoditi cengkeh Singapura memiliki daya saing. Singapura bukanlah negara produsen cengkeh, namun demikian Singapura merupakan negara eksportir terbesar karena melakukan kegiatan re-ekspor cengkeh. Kontribusi ekspor Singapura sebesar $65,99 \%$ terhadap ASEAN (periode 1980-2011), sedangkan Indonesia dan Malaysia berkontribusi $31,49 \%$ dan $2,49 \%$ (Kementerian Pertanian, 2014). Pada periode 20012011 meskipun nilai RSCA kurang dari 1, namun masih lebih besar dibandingkan Indonesia dan Malaysia. Hal ini juga ditunjukkan dengan nilai rata-rata RSCA untuk Singapura sebesar 0,96 dan lebih besar dibandingkan Indonesia sebesar 0,22 dan Malaysia sebesar $-0,25$.

\subsection{Analisis Keunggulan Kompetitif}

Analisis keunggulan kompetitif menggunakan Indeks Spesialisasi Perdagangan (ISP) sehingga dapatlah diketahui posisi atau tahapan perkembangan komoditi cengkeh Indonesia, Malaysia dan Singapura. Indeks ini dapat memberi gambaran apakah spesialisasi ketiga negara ini sebagai negara importir ataukah eksportir cengkeh, hasil analisis dilihat pada Tabel 3.

Tabel 3. Nilai Indeks Spesialisasi Perdagangan Negara-Negara ASEAN Tahun 1980-2011

\begin{tabular}{cccc}
\hline \multirow{2}{*}{ Periode } & \multicolumn{3}{c}{ Nilai Indeks Spesialisasi Perdagangan (ISP) } \\
\cline { 2 - 4 } & Indonesia & Malaysia & Singapura \\
\hline $1980-1986$ & $-0,48$ & 0,05 & 0,02 \\
$1987-1993$ & 0,85 & $-0,14$ & $-0,17$ \\
$1994-2000$ & 0,52 & $-0,51$ & 0,00 \\
$2001-2007$ & 0,95 & $-0,94$ & $-0,10$ \\
$2008-2011$ & 0,46 & $-0,72$ & $-0,17$ \\
Rata-rata & 0,46 & $-0,45$ & $-0,09$
\end{tabular}

Sumber : Data Primer 2015

Tabel 3 menunjukkan bahwa nilai ISP Indonesia pada periode 1980-1986 sebesar $-0,48$ berarti pada periode tersebut komoditi cengkeh Indonesia pada tahap pengenalan dalam perdagangan dunia atau memiliki daya saing rendah, dimana pada periode itu impor cengkeh lebih besar dibandingkan ekspor. Pada periode
1987-1993 dan periode 2001-2007, nilai ISP Indonesia sebesar 0,85 dan 0,95 artinya komoditi cengkeh Indonesia pada tahap pematangan dan memiliki daya saing yang kuat. Sedangkan pada periode 1994-2000 dan 2008-2011, nilai ISP sebesar 0,52 dan 0,46 berarti komoditi cengkeh Indonesia dalam tahap perluasan ekspor dan memiliki daya 
saing yang kuat. Fluktuasinya nilai ISP disebabkan ekspor dan impor cengkeh Indonesia pun selalu berfluktuasi, dimana saat panen besar di dalam negeri akan mendorong ekspor, dan sebaliknya saat panen menurun maka impor akan meningkat. Namun demikian nilai ISP Indonesia per periode maupun rata-rata ISP masih lebih besar dibandingkan Malaysia dan Singapura.

Rata-rata nilai ISP Malaysia berkisar $-0,45$, hal itu berarti komoditi cengkeh Malaysia pada tahap substitusi impor dalam perdagangan dunia. Sedangkan nilai rata-rata ISP Singapura sebesar 0,09, menunjukkan bahwa Singapura sebagai pengimpor komoditi cengkeh. Hal ini ditunjukkan data FAOStat dalam Kementerian Pertanian (2014) bahwa Singapura merupakan negara eksportir sekaligus juga importir cengkeh terbesar di ASEAN bahkan di dunia. Khusus di kawasan ASEAN, kontribusi impor Singapura sebesar $64,64 \%$, sedangkan Indonesia dan Malaysia sebesar 23,91\% dan 5,68\%.

\section{PENUTUP}

4.1. Kesimpulan

Berdasarkan hasil penelitian maka disimpulkan hal-hal berikut :

1. Analisis menunjukkan ekspor cengkeh Indonesia terus meningkat pada tahun 20152018. Tahun 2015 ini diramalkan sebesar 10606,86 ton, tahun 2016 sebesar 10943,20 ton, tahun 2017 sebesar 11279,54 ton, dan tahun
2018 sebesar 11615,88 ton dengan rata-rata pertumbuhan sebesar 3,08 \% per tahun.

2. Daya saing Indonesia memiliki keunggulan komparatif yang rendah ditingkat dunia dengan nilai indeks RSCA sebesar 0,22 serta memiliki keunggulan kompetitif dengan ISP sebesar 0,46 artinya komoditi cengkeh dalam tahap perluasan ekspor. Malaysia memiliki keunggulan komparatif yang rendah pasar dunia dimana nilai indeks RSCA sebesar 0,25. Keunggulan kompetitif Malaysia juga rendah dimana ISP sebesar $-0,45$ menunjukkan perkembangan komoditi cengkeh Malaysia pada tahap substitusi impor. Sedangkan Singapura memiliki keunggulan komparatif yang tinggi dibandingkan Indonesia dan Malaysia, dimana rata-rata indeks RSCA sebesar 0,96. Namun Singapura memiliki keunggulan kompetitif yang rendah ditunjukkan nilai ISP sebesar -0,09, menunjukkan bahwa Singapura sebagai pengimpor komoditi cengkeh.

\subsection{Saran}

Berdasarkan hasil penelitian dapat disarankan untuk peningkatan keunggulan komparatif dan kompetitif cengkeh Indonesia dapat dilakukan melalui peningkatan intensifikasi, rehabilitasi, dan peremajaan tanaman yang pada akhirnya akan mendorong produksi, pemenuhan permintaan industri rokok, dan ekspor.

\section{DAFTAR PUSTAKA}

Asriani, Putri Suci, 2011. Analisis Daya Saing Ekspor Ubikayu Indonesia, Jurnal Agroland 18 (1) : $65-70$.

Departemen Perdagangan, 2008. Indeks Spesialisasi Perdagangan (ISP), http://www.kemendag.go.id/addon/isp/index.php?isi=1, diakses 25 April 2015. 2010. Menuju ASEAN Economic Community 2015, Ditjen Kerjasama Perdagangan Internasional, Jakarta.

Departemen Pertanian, 2007. Prospek Dan Arah Pengembangan Agribisnis Cengkeh Edisi Kedua, Badan Penelitian Dan Pengembangan Pertanian.

FAOSTAT, 2015. TradeSTAT Crops and Livestock Products, http://faostat.org, diakses 1 April 2015. 
Hanani, Nuhfil, Rachman Hartono, Luh Putu Ayu Ratnadi, 2009. Analisis Tingkat Daya Saing Ekspor Buah-Buahan Indonesia, Jurnal Agrise Volume IX No. 1.

Kementerian Pertanian, 2013. Kinerja Perdagangan Komoditi Pertanian, Volume 4 No. 1, Pusat Data Dan Sistem Informasi Pertanian. 2014. Outlook Komoditi Cengkeh, Pusat Data dan Sistem Informasi Pertanian, Jakarta.

Prawirosentono, Suyadi, 2009. Manajemen Operasi (Operations Management): Analisis dan Studi Kasus, Edisi Keempat, Bumi Aksara, Jakarta.

Ragimun, 2013. Analisis Daya Saing Komoditas Kakao Indonesia, Pusat Kebijakan Ekonomi Makro Badan Kebijakan Fiskal Kemenkeu, Jakarta.

2014. Analisis Daya Saing Karet Dan Produk Dari Karet Indonesia Terhadap China, Pusat Kebijakan Ekonomi Makro Badan Kebijakan Fiskal Kemenkeu, Jakarta.

Rashid Anggit Y.A.D, Ni Made Suyastiri Y.P, Antik Suprihanti, 2012. Analisis Daya Saing Crude Palm Oil (CPO) Indonesia Di Pasar Internasional, Jurnal SEPA Volume 9 No. 1: 125 - 133.

Rianse, Usman dan Abdi, 2009. Metodologi Penelitian Sosial dan Ekonomi (Teori dan Aplikasi), Edisi Pertama, Alfabeta, Bandung.

Tambunan, T., 2003a. Perdagangan Internasional dan Neraca Pembayaran, Teori dan Temuan Empiris, LP3ES, Jakarta.

, 2003b. Perkembangan Sektor Pertanian di Indonesia Beberapa Isu Penting, Ghalia Indonesia, Jakarta.

2004. Globalisasi dan Perdagangan Internasional, Ghalia Indonesia-Anggota IKAPI, Bogor.

Wikipedia, 2015. Cengkih, http://id.wikipedia.org/wiki/Cengkih, diakses 24 April 2015. 